\title{
Kraft and Diamond Dotted paper thermally aged in mineral oil and natural ester: mechanical characterisation
}

\author{
Cristina Fernández-Diego \\ Electrical and Energy Engineering Dep. \\ University of Cantabria \\ Santander, Spain \\ fdezdiegoc@unican.es \\ Inmaculada Fernández \\ Electrical and Energy Engineering Dep. \\ University of Cantabria \\ Santander, Spain \\ fernandei@unican.es
}

\author{
Alfredo Ortiz \\ Electrical and Energy Engineering Dep. \\ University of Cantabria \\ Santander, Spain \\ ortizfa@unican.es \\ Fernando Delgado \\ Electrical and Energy Engineering Dep. \\ University of Cantabria \\ Santander, Spain \\ fernando.delgado@unican.es
}

\author{
Isidro A. Carrascal \\ LADICIM \\ University of Cantabria \\ Santander, Spain \\ isidro.carrascal@unican.es \\ Cristian Olmo \\ Electrical and Energy Engineering Dep. \\ University of Cantabria \\ Santander, Spain \\ cristian.olmo@unican.es
}

\begin{abstract}
Oil-immersed transformers, whose lifespan is defined by cellulose insulation's lifetime, utilize frequently mineral oil. However, this insulating fluid is being replaced by alternative liquids such as natural and synthetic esters. This replacement requires to guarantee a similar behavior of solid insulating materials immersed in them. Although there are different authors who have concluded that Kraft paper reduces its deterioration rate when it is immersed in biodegradable fluids, there are few works that have analyzed the effect of insulation liquids on the mechanical properties of other cellulosic materials such as diamond dotted paper (DDP) during laboratory tests. This paper shows a comparative analysis of four paper/oil specimens (a standard Kraft paper and a diamond dotted paper aged in both mineral oil and natural ester) under controlled laboratory accelerated thermal ageing. This work focuses on changes in mechanical properties such as the energy consumed per unit volume of the failure zone $\left(E_{R}\right)$, rupture strength $\left(\sigma_{R}\right)$ and strain under ultimate strength $\left(\varepsilon_{\mathrm{cm}}\right)$.
\end{abstract}

Keywords- Electric power transformers, Kraft paper, DDP paper, dielectric oil, tensile test, thermal aging

\section{INTRODUCTION}

Transformers are devices of enormous importance in current distribution systems [1]. The insulation in these machines is usually a combination of liquid and solid dielectric materials [2]. The lifetime of transformers depends on paper deterioration because dielectric oil's life can be prolonged through filtering and reconditioning or even the oil can be replaced easily. The insulating fluid widely used in oilimmersed transformers is mineral oil. However, this fluid has started to be substituted especially in distribution transformers for alternative liquids such as natural and synthetic esters [3] mainly due to their higher biodegradability and fire safety properties [4-8].

Many authors have analyzed ageing behavior of different insulation papers immersed in natural and synthetic esters [924]. These studies and others have found that thermal ageing rates of insulation solids immersed in natural esters are reduced compared to those in mineral oil [9]. The insulation solids usually studied include papers such as Kraft paper [1016], thermally upgraded papers [9, 17-19], aramid paper [1, 20-21], pressboard [20, 22]. The paper degradation in thermal aging studies has been evaluated through the degree of polymerization [10-12, 18-19], the tensile strength [13-16, 19-23], differential scanning calorimetry [24], Fourier transform infrared spectroscopy (FTIR) or energy dispersive $\mathrm{X}$-ray [12] being the DP and the tensile strength the most commonly used methods to evaluate the insulating paper condition. Even though, the degradation suffered by different insulation papers immersed in biodegradable oils during thermal ageing tests has been studied, there are few works that have analyzed the effect of insulation liquids on the deterioration of other cellulosic materials such as Diamond Dotted paper (DDP). The advantage of this insulation paper lies in the internal strengthening of the coil from adhesion to the conductor; providing passage for quick evacuation of air and moisture during the drying process. It also minimizes the risk of partial discharge. The bonding strength of the epoxy resin is sufficient to prevent displacement of winding layers due to short circuit forces [25].

Accurate diagnosis of transformer ageing is critical to ensure safe operation of transformers [26]. The application of natural esters, makes needed the diagnostic of the aging state of insulation paper mainly because its degradation determine the operational lifetime of a transformer [27]. Based on that, this paper presents experimental results of the study of mechanical properties changes in DDP paper compared with Kraft paper when they are immersed and aged in two commercial insulation liquids (a mineral oil and a natural ester). This work focuses on three mechanical properties: the energy consumed per unit volume of the failure zone $\left(E_{R}\right)$, rupture strength $\left(\sigma_{\mathrm{R}}\right)$ and strain under ultimate strength $\left(\varepsilon_{\mathrm{cm}}\right)$.

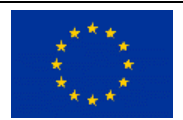




\section{MATERIAL}

This work has analyzed the behavior of Kraft and Diamond Dotted papers (Table I), when they are thermally aged in two different commercial oils (Table II).

TABLE I PAPERS' PROPERTIES

\begin{tabular}{|l|c|c|c|}
\hline \multicolumn{1}{|c|}{ Property } & Units & $\begin{array}{c}\text { Kraft } \\
\text { paper }\end{array}$ & $\begin{array}{c}\text { Diamond Dotted } \\
\text { paper (DDP) }\end{array}$ \\
\hline Apparent density & $\mathrm{g} / \mathrm{m}^{2}$ & 0.754 & 1 \\
\hline $\begin{array}{l}\text { Dry breakdown strength } \\
\text { in air }\end{array}$ & $(\mathrm{kV} / \mathrm{mm})$ & 8.9 & 10 \\
\hline Ash content & $\%$ & $<0.6$ & 0.3 \\
\hline Tensile index & $(\mathrm{Nm} \mathrm{g)}$ & 108.4 & 160 \\
\hline
\end{tabular}

TABLE II PROPERTIES OF ANALYZED OILS

\begin{tabular}{|l|c|c|c|}
\hline \multicolumn{1}{|c|}{ Property } & Units & $\begin{array}{c}\text { Mineral } \\
\text { oil (MO) }\end{array}$ & $\begin{array}{c}\text { Vegetable } \\
\text { oil (VO) }\end{array}$ \\
\hline Viscosity, $40^{\circ} \mathrm{C}$ & $\left(\mathrm{mm}^{2} / \mathrm{s}\right)$ & 7.6 & 39.2 \\
\hline Density, $20^{\circ} \mathrm{C}$ & $\mathrm{kg} / \mathrm{dm}^{3}$ & 0.877 & 0.91 \\
\hline Pour point & ${ }^{\circ} \mathrm{C}$ & -63 & -25 \\
\hline Flash point & ${ }^{\circ} \mathrm{C}$ & 154 & 330 \\
\hline Water content & $\mathrm{mg} / \mathrm{kg}$ & $<20$ & 150 \\
\hline Breakdown voltage & $\mathrm{kV}$ & $40-60$ & 65 \\
\hline Acidity & $\mathrm{mg} \mathrm{KOH} / \mathrm{g}$ & $<0.01$ & 0.05 \\
\hline $\begin{array}{l}\text { Dielectric dissipation factor } \\
\left(90^{\circ} \mathrm{C}\right)\end{array}$ & & $<0.001$ & 0.03 \\
\hline
\end{tabular}

The mineral oil is a naphthenic oil and the vegetable oil is a rapeseed-based fluid.

\section{EXPERIMENTAL METHODOLOGY}

This section describes the steps followed during accelerated thermal ageing of Kraft and DDP papers immersed in two different dielectric oils. Firstly, the size of paper specimens is defined. Secondly, the procedure to carry out a previous drying of paper samples is explained. Thirdly, the thermal ageing conditions are gathered. Finally, the test used to characterize paper degradation is described.

\section{A. Paper samples}

Kraft and DDP papers were cut into strips of $250 \mathrm{~mm}$ in length and $15 \mathrm{~mm}$ wide. These strips were cut with two different fiber direction angles (longitudinal and transverse) because of paper anisotropy.

\section{B. Paper drying}

Previously its thermal ageing, Kraft and DDP specimens were dried to reduce the effect of moisture on the degradation. Drying was carried out placing paper strips into a stainless steel vessel, which was closed. Subsequently, it was connected to a vacuum pump until reaching approximately 1 mbar. It was sited then in an oven at $100^{\circ} \mathrm{C}$ for 24 hours, providing samples with a moisture content around $2 \%$.

\section{Thermal ageing}

A vessel for each temperature and each oil was prepared by inserting $750 \mathrm{ml}$ of new oil (mineral and vegetable oil) with a nitrogen headspace of $25 \%$ by volume, and $22 \mathrm{~g}$ of paper giving a paper/oil weight-volume ratio of 1:34. The thermal ageing was then carried out in two ovens at $130^{\circ} \mathrm{C}$ and $150^{\circ} \mathrm{C}$. After each aging time (Table III) was reached, the vessels were cooled at room temperature $\left(25^{\circ} \mathrm{C}\right)$ and then the paper samples were extracted for analysis. In this work, for each fiber direction, 7 groups of strips for both papers were prepared, one group of new paper and the rest of thermal aged samples. Five paper strips per group, which were tested in the tensile test, were prepared.

TABLE III TIME OF THERMAL AGEING

\begin{tabular}{|l|c|c|c|c|c|}
\hline \multirow{2}{*}{ Samples } & \multicolumn{5}{|c|}{ Ageing time } \\
\cline { 2 - 6 } & \multicolumn{4}{|c|}{$150^{\circ} \mathrm{C}$} & \multicolumn{2}{c|}{$130^{\circ} \mathrm{C}$} \\
\cline { 2 - 6 } & \multicolumn{2}{|c|}{ Kraft } & DDP & Kraft & DDP \\
\cline { 2 - 6 } & MO & VO & MO/VO & MO/VO & MO/VO \\
\hline 0 & 0 & 0 & 0 & 0 & 0 \\
\hline 1 & 8 & 24 & 81 & 72 & 62,5 \\
\hline 2 & 19 & 48 & 404.5 & 168 & 133,5 \\
\hline 3 & 43 & 96 & 1040 & 261 & 225 \\
\hline 4 & 91 & 147 & 1920 & 425 & 453,5 \\
\hline 5 & 142 & 217 & 3676.5 & 736 & 686 \\
\hline 6 & 212 & 494 & 6784 & 1083 & 9787 \\
\hline
\end{tabular}

\section{Characterisation of paper ageing}

The data obtained from tensile test (load and displacement) are used to determine stress and strain using the original specimen cross-sectional area. These two parameters allow to obtain stress-strain curve which can be utilized to obtain additional information such as the energy consumed per unit volume of the failure zone $\left(E_{R}, P a\right)$, rupture strength $(\sigma R, P a)$, strain under ultimate strength $\left(\varepsilon_{\mathrm{cm}}\right)$ and tensile index (TI, $\mathrm{kN} \mathrm{m}^{-1} \mathrm{~kg}^{-1}$ ).

In this work, a universal servo hydraulic test machine (Model ME-405-1, SERVOSIS) was used with an axial load cell of $\pm 1 \mathrm{kN}$ capacity, an actuator of $\pm 50 \mathrm{~mm}$ of dynamic stroke and equipped with pneumatic flat grips. The length of the paper strips for the measurement of the strain was set at $180 \mathrm{~mm}$ and the rate of separation of the grips was set at 20 $\mathrm{mm} / \mathrm{min}$ until the specimen rupture, according to ISO 19242 2009. Alghough, the parameters obtained in the test can be Young's Modulus $(E)$, yield stress $\left(\sigma_{y}\right)$, rupture strength $\left(\sigma_{R}\right)$, strain under ultimate strength $(\varepsilon \mathrm{cm})$, and energy consumed per unit volume of the failure zone $\left(E_{R}\right)$. However, in this work only $\sigma_{R}, \varepsilon_{c m}$ and $E_{R}$ were evaluated because in a previous work [28] the experimental results showed that Young's Modulus and yield stress can hardly provide any information on the degree of degradation. In the case of Young's Modulus, their values were practically the same during the thermal ageing period. It was only in those states of severe degradation did they show a slight decrease. As for the yield stress, in more than half of the analyzed samples its value was the same as that of the rupture strength, due to the fragility of the most deteriorated samples. Therefore, the parameters of rupture strength, strain under ultimate strength and energy consumed per unit volume of the failure zone are which really expose paper degradation.

\section{RESULTS AND ANALYSIS}

When the mechanical properties of the new papers are measured, a strong anisotropy has been verified. It can be observed that the rupture strength, when the paper fibres are 
in the same direction as that with which the test machine applies the load, is two times the strength obtained when the fibres are in cross direction to the test machine, while the strain is half.

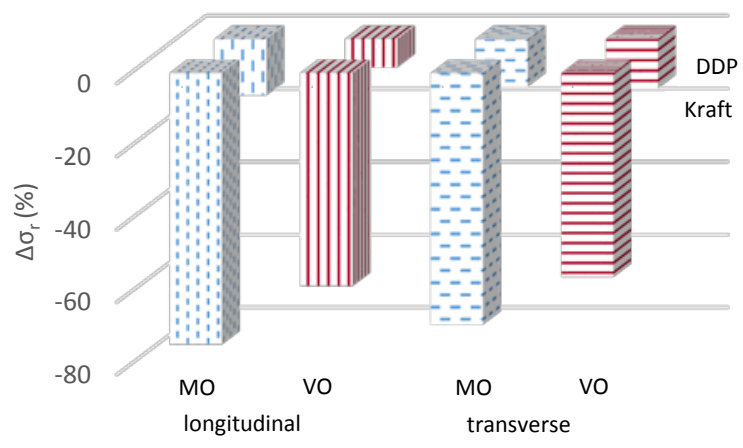

Fig. 1. Rupture strength $\left(\sigma_{R}\right)$ variation of Kraft and DDP papers aged at $150^{\circ} \mathrm{C}$.

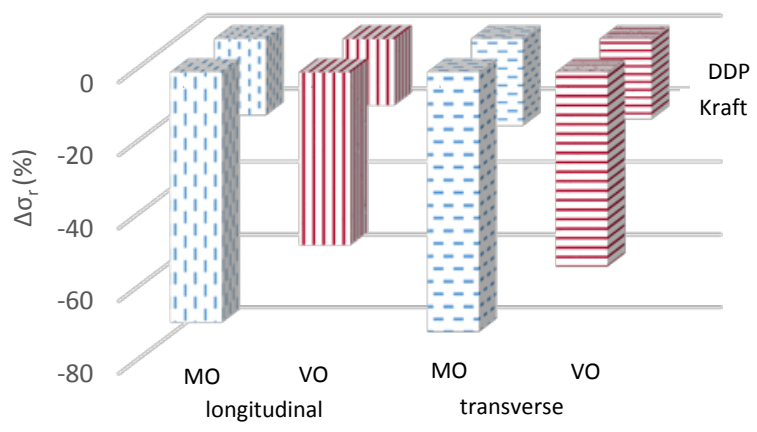

Fig. 2. Rupture strength $\left(\sigma_{\mathrm{R}}\right)$ variation of Kraft and DDP papers aged at $130^{\circ} \mathrm{C}$.

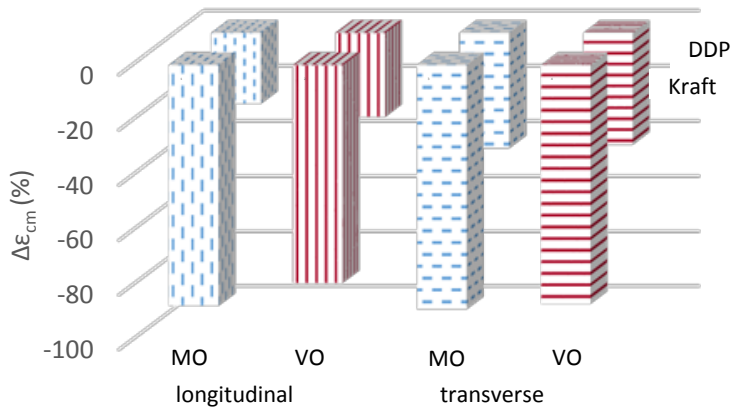

Fig. 3. Strain under ultimate strength $\left(\varepsilon_{\mathrm{cm}}\right)$ variation of Kraft and DDP papers aged at $150^{\circ} \mathrm{C}$.

Figs. 1 and 2 show the rupture strength $\left(\sigma_{R}\right)$ reduction suffered by both dielectric papers (Kraft and DDP) aged in the mineral oil and the vegetable oil, at two different temperatures. It can be observed that in both papers the deterioration is higher in mineral oil at $150^{\circ} \mathrm{C}$. However, when results obtained for DDP are compared at $130^{\circ} \mathrm{C}$, there is no difference between paper samples aged in mineral or vegetable oil.

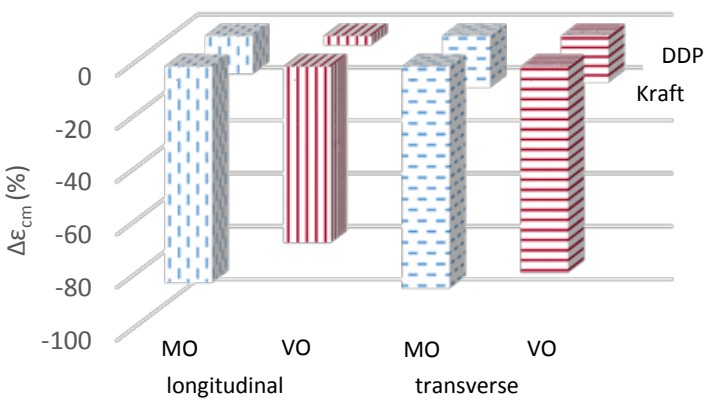

Fig. 4. Strain under ultimate strength $\left(\varepsilon_{\mathrm{cm}}\right)$ variation of Kraft and DDP papers aged at $130^{\circ} \mathrm{C}$.

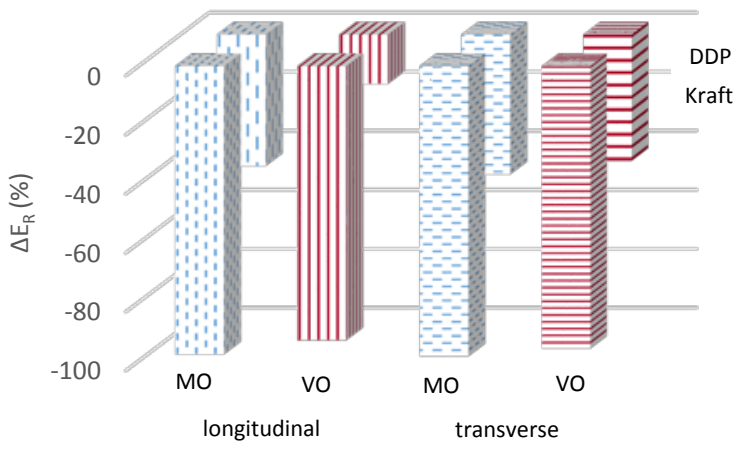

Fig. 5. Energy consumed per unit volume of the failure zone $\left(E_{R}\right)$ variation of Kraft and DDP papers aged at $150^{\circ} \mathrm{C}$.

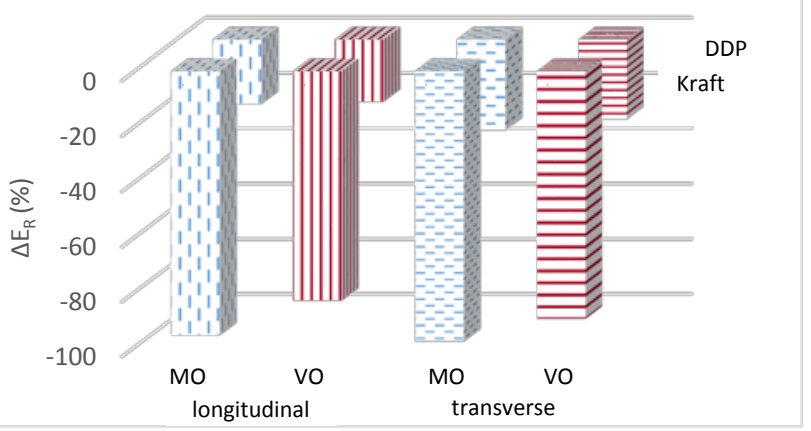

Fig. 6. Energy consumed per unit volume of the failure zone $\left(E_{R}\right)$ variation of Kraft and DDP papers aged at $130^{\circ} \mathrm{C}$.

Similar results have been found for the rest of analyzed properties (Figs. 3-6). The mechanical strength showed for DDP is considerable greater than the Kraft paper's one for both fiber directions. This can be observed through the decreases suffered by the $\sigma_{\mathrm{R}}$ during thermal ageing for Kraft and DDP papers. When the ageing temperature is lower $\left(130^{\circ} \mathrm{C}\right)$ the $\sigma_{R}$ of Kraft suffers a reduction more than twice the one experienced by DDP in percentage of variation. If 
these data are compared when the temperature is $150^{\circ} \mathrm{C}$, the difference is even greater. This fact reflects the strong effect that temperature also has on the least resistant paper.

\section{CONCLUSIOS}

In this paper the stability of two different papers (Kraft and DDP) present in different dielectric systems (oil-paper) has been analyzed through three parameters obtained from the tensile test, when these systems are subjected to accelerated thermal ageing in an inert atmosphere of nitrogen, in laboratory tests.

The obtained results have shown that paper anisotropy plays a critical role. In both papers there is a significant difference in the values of the mechanical properties such as $E_{R}, \sigma_{R}$ or $\varepsilon_{c m}$, depending on the way in which tensile test is carried out. When fibers of cellulose materials are aligned along the paper machine direction (longitudinal) the paper's tensile strength is higher than when fibers are in the cross direction (transverse). Therefore, it is critical to determine the evolution of mechanical properties in both directions as this might affect paper placement inside power transformer windings to increase its mechanical resistance. Additionally, it has been found that the behavior shown by Kraft and DDP papers is quite different. The natural ester seems to protect Kraft paper when this is aged at $150^{\circ} \mathrm{C}$ and $130^{\circ} \mathrm{C}$, however, when the DDP degradation in both liquids is compared, there is a slight difference only when temperature is high. Consequently, it seems that beneficial effect of natural ester on paper ageing is reduced when highly resistant insulation papers are considered.

\section{REFERENCES}

[1] C. Ranga and A. K. Chandel. "Life assessment of TUK and Nomex910 impregnated mineral transformer oils using Raman spectroscopy," $3^{\text {rd }}$ Int. Conf. Condit. Assess. Techniq. Electric. Systs (CATCON), Rupnagar, India, pp. 16-18, 2017.

[2] M. Ariannik, A. A. Razi-Kazemi, and M. Lehtonen, "Effect of Cumulative Moisture Content on Degradation of Transformer Paper Insulation,” IEEE Trans. Dielectr. Electr. Insul., vol. 24(1); pp. 617618, 2017.

[3] Pow, S. P. Moore, W. Wangard, K. J. Rapp, D. L. Woods, and R. M. Del Vecchio, "Cold Start of a 240-MVA Generator Step-Up Transformer Filled With Natural Ester Fluid," IEEE Trans. Power Deliv., vol. 30(1), pp. 256-263, 2015.

[4] K. Bandara, C. Ekanayake and T. K. Saha. "Compare the performance of natural ester with synthetic ester as transformer insulating oil,” IEEE $11^{\text {th }}$ Int. Conf. Propert. Applic. Dielectr. Mater. (ICPADM), 2015.

[5] M. Lashbrook, A. Gyore, and R. Martin, "A review of the fundamental dielectric characteristics of ester-based dielectric liquids," Procedia Eng., vol. 202, pp. 121-129, 2017.

[6] P. Przybylek, "Drying transformer cellulose insulation by means of synthetic ester," IEEE Trans. Dielectr. Electr. Insul., vol. 24, no. 4, pp. 2643-2648, 2017

[7] I. Fernández, A. Ortiz, F. Delgado, C. Renedo, and S. Pérez, "Comparative evaluation of alternative fluids for power transformers," Electr. Power Syst. Research, vol. 98, pp. 58-69, 2013.

[8] A. Johari, A. A. Suleiman, N. Bashir, N. A. Muhamad, M. H. Ahmad and I. M. Inuwa, "Performance of biodegradable insulating oil under accelerated thermal ageing,” IEEE Int. Conf. Power Energ. (PECon), pp. 9-12, 2014.

[9] K. J. Rapp and J. Luksich. "Review of Kraft paper/natural ester fluid insulation system aging,” IEEE Int. Conf. Dielectr. Liquid. (ICDL), Trondheim, Norway, 2011.

[10] R. Liao, J. Hao, L. Yang and S. Grzybowski. "Study on aging characteristics of mineral oil/natural ester mixtures-paper insulation," IEEE Int. Conf. Dielectr. Liquid. (ICDL), Trondheim, Norway, 2011.
[11] B. Garcia, T. Garcia, V. Primo, J. C. Burgos and D. Urquiza, "Studying the loss of life of natural-ester-filled transformer insulation: impact of moisture on the aging rate of paper," IEEE Electr. Insul. Mag., vol. 33, pp. 15-23, 2017.

[12] A. Munajad and C. Subroto, "Study on the effects of thermal aging on insulating paper for high voltage transformer composite with natural ester from palm oil using Fourier transform infrared spectroscopy (FTIR) and energy dispersive X-ray spectroscopy (EDS),” Energies, vol. 10, pp. 1857, 2017.

[13] T. Suzuki, T. Kano, A. Kanetani, S. Hatada, and F. Kurihara. "Comparative study of the insulation paper aging in palm fatty acid ester (PFAE) and mineral oil,” IEEE $18^{\text {th }}$ Int. Conf. Dielectr. Liquid. (ICDL), Bled, Slovenia, 2014

[14] AA. Abdelmalik, "Analysis of thermally aged insulation paper in a natural ester-based dielectric fluid", IEEE Transactions on Dielectrics and Electrical Insulation, vol. 22(5), pp. 2408-2414, 2015.

[15] T. Widyanugraha, R. Rachmad, Wendhy and Suwarno. "DGA and tensile strength test on accelerated thermal aging of ester oil and Kraft paper" presented at the 5th International Conference on Electrical Engineering and Informatics (ICEEI), Bali, Indonesia, pp. 177-180, 2015.

[16] NA. Raof, U. Rashid, R. Yunus, N. Azis and Z. Yaakub, "Development of palm-based neopentyl glycol diester as dielectric fluid and its thermal aging performance”, IEEE Transactions on Dielectrics and Electrical Insulation, vol. 23(4), pp. 2051-2058, 2016.

[17] LE.. Lundgaard, W. Hansen, D. Linhjell, and TJ. Painter, “Aging of Oil-Impregnated Paper in Power Transformers", IEEE transactions on power delivery, vol. 19(1), Jan 2004.

[18] J. Tokunaga, H. Koide, K. Mogami and T. Hikosaka, "Comparative studies on the aging of thermally upgraded paper insulation in palm fatty acid ester mineral oil and natural ester", IEEE Transactions on Dielectrics and Electrical Insulation, vol. 23, pp. 258-265, 2016.

[19] C. Subroto, A. Munajad and Suwarno. "Lifetime estimation of cellulose paper in natural ester dielectric fluid", presented at the International Conference on High Voltage Engineering and Power Systems (ICHVEPS), Sanur, Indonesia, pp. 307-311, 2017.

[20] D. Saruhashi, X. Bin, L. Zhiyuan and S. Yanabu, "Thermal degradation phenomena of flame resistance insulating paper and oils", IEEE Transactions on Dielectrics and Electrical Insulation, vol. 20(1), pp. 122-127, 2013.

[21] K. J. Rapp and J. Luksich "Accelerated aging of aramid insulation in various dielectric liquids", IEEE $18^{\text {th }}$ International Conference on Dielectric Liquids (ICDL), Bled, Slovenia, 2014.

[22] J. Tokunaga, H. Koide, K. Mogami, K. Kawanishi and T. Hikosaka, "Lifetime estimation of cellulosic insulation material in palm fatty acid ester for power transformers”, IEEE Trans. Dielectr. Electr. Insul, vol. 24, pp. 1010-1017, 2017.

[23] R. Madavan and S. Balaraman "Failure analysis of transformer liquid - solid insulation system under selective environmental conditions using Weibull statistics method”, Eng. Failure Analysis, vol. 65, pp. 26-38, 2016.

[24] R. Setnescu, L. V. Badicu, L. M. Dumitran, P. V. Notingher, and T. Setnescu, "Thermal lifetime of cellulose insulation material evaluated by an activation energy based method", Cellulose, vol. 21(1), pp. 823833, 2014.

[25] ABB. Transformer insulation paper. [Available in: https://new.abb.com/ products/transformers/ transformercomponents/insulation-components-and-materials/transformerinsulation-paper/raman-sigma-diamond-dotted-paper]

[26] G. Chao, Z. Mengzhao, Z. Wenbing, J. Hao, and R. Zou, "Thermal ageing condition assessment for transformer using natural ester-paper insulation based on polarization and depolarization current,” Int. Conf. Diagnost. Electric. Eng. (Diagnostika), pp. 1-4, 2018.

[27] R. Liao, S. Liang, L. Yang, J. Hao, and J. Li, "Comparison of ageing results for transformer oil-paper insulation subjected to thermal ageing in mineral oil and ageing in retardant oil," IEEE Trans. Dielectr. Electr. Insul., vol. 19(1), pp. 225-232, 2012.

[28] I. A. Carrascal, C. Fernández-Diego, J. A. Casado, S. Diego, I. Fernández, and A. Ortiz, "Quantification of Kraft paper ageing in mineral oil impregnated insulation systems through mechanical characterization,” Cellulose, vol. 25(6), pp. 3583-3594, 2018. 